\title{
Effect of Aqueous Olive Leaves Extract on the Pancreatic Islets in Rats
}

\author{
Khabat A. Ali \\ Department of Biology/College of Education/ University of Salahaddin/ Erbil
}

(Received 12 / 6/2013 ; Accepted 18 / 8/2013)

\begin{abstract}
The objectives of this study were to investigate the effects of the aqueous crude extract of Olea europaeaon serum glucose level and histopathological changes in islets of Langerhans in an induced-diabetic mellitus in rats. The hypoglycemic activity of Olive leaf extract was investigated in fasting health rats and alloxan-diabetic rats. Blood samples were collected from the tail of rats and serum glucose measured on the 1st, 15th, 30th days of the experiment. A significant reduction in blood glucose of diabetic animal's $\left(350.5 \pm 0.0348^{\mathrm{e}}\right) \mathrm{mg} / \mathrm{dl}$ in case of administration of Olive leaves in comparison with diabetic control $\left(373.4 \pm 0.0562^{a}\right) \mathrm{mg} / \mathrm{dl}$. The present study clearly indicated a significant antidiabetic activity with the Olive leaves and supports the traditional usage for the control of diabetes (Nadar et al., 2003), Aqueous crude extract considered as hypoglycemic agent reduce oxidative stress, indirectly by lowering blood glucose and preventing hyperinsulinemia (Casalino et al., 2002). The study showed islets of Langerhans continuous infarctions and lymphocyte infiltration in alloxan-diabetic rats while the treatment group showed the islets irregularity in size, but they appeared normal with decreased granulation and some islets appeared very small, all of islets appeared normal as of the control animals.
\end{abstract}

Keywords: Alloxan, Diabetes Mellitus, hypoglycemic plant, Olive leaves, anti- hyperglycemic, antioxidant.

تأثير المستخلص المائي لأوراق الزيتون على جزر لنكرهانس في الجرذان

الهذف من هذه الدرلسة شتخيص تأثير المستخلص المائي لأوراق الزيتون Olea europaea لمستويت الكلوكوز في

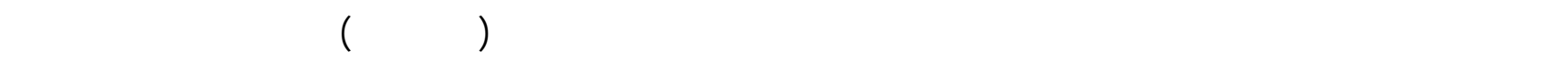
والمعلملة. وقسمب و جمع نماذج الدم من نل الجرذان في اليوم الاول واليو 15 و30 من التجربة. وكانت النتائج معنوية

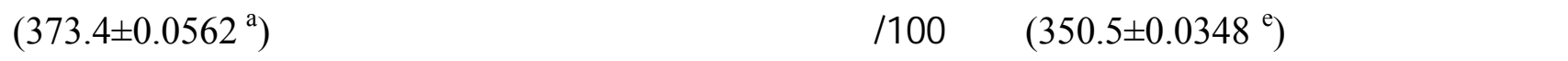

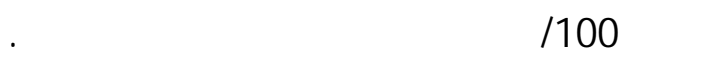
و أوضحت الدرلسة تأثير المستخلص المائي لأوراق الزيتون على جزر لنكرهانس للسكر المحدث (ففعل الالوكسان) اذ فاذ

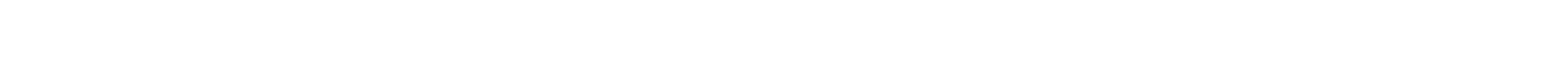
للخلايا الليماوية ووجود تغيرات حجمية وشكلية في الجزر في حن أدى في الجرذان المعلملة المريضة إلى القللي من هذه فئه التغيرات في الجزر وندرة تضضم الخلايا وبالتالي فأن الجزر تبدو إلى حدماطبية الجزيعية مقارنة بمجموعة الليطية السيطرة.

\section{INTRODUCTION}

Diabetes mellitus (DM) is a metabolic disorder characterized by hyperglycemia due to defective insulin action, insulin secretion or both. It is a complex and multifarious group of disorders characterized by hyperglycemia that has reached epidemic proportions in the present century (Noor et al., 2008).

Diabetes Type 2 is characterized by hyperglycemia, peripheral resistance to the action of insulin, and are eventual destruction of insulin producing $\beta$-cells in the pancreas (Abu-Zaiton and 
Mariam, 2012). Diabetic patients are at an increased risk for cardiovascular disease, blindness, nerve and kidney damage, and limb amputations. Diabetics are also at a greater risk for developing different cancers due to the immunological disturbances induced by aberrant metabolism. Obesity is a major predisposing factor in the development ofdiabetes. In obese populations, inflammatory molecules produced by adipose tissue and increased circulation of free fatty acid (FFA) play an important role in producing peripheral insulin resistance as well as increasing damage to the insulinproducing $\beta$-cells. The main treatments for type 2 diabetes include diet, exercise, andseveral medicinal plants are used in the management of DM (Akah et al., 2002; Verspohl, 2002 ; Colca, 2006).

Currently, many herbal medicines therapeutic available have been recommended for the treatment of diabetes. Herbal drugs are prescribed widely because of their effectiveness, less side effects and a relatively low cost (Venkatesh et al., 2003).

Olive (Olea europaea L.) phenolics are known as powerful antioxidants, both in vitro and in vivo and it is known that olive oil represents a key healthy component of Mediterranean diet (Karakaya, 2009). Not only olive oil, but olive leaf also has different beneficial effects on human health. Compounds obtained from olive leaf extracts (OLE) have been subject to numerous investigations (Nadar et al., 2003), OLE from Mediterranean olive has been commercialized as a food supplement, which can be consumed in the form of tea, syrup and capsules. OLE is wellknown for its hypotensive effects and its antioxidant properties, hypoglycemic, cardio protective antimicrobial, radio protective, antiatherogenic, antitumoral, anti-inflammatory, hypocholosterolemic, hepato-protective and anti-viral properties. The main constituent of the olive leaf is the iridoid glycoside oleuropein, which is metabolized in the body to calcium elenolate, which is apparently responsible for many of the pharmacological actions of the olive leaf. Furthermore, the olive leaf contains triterpenes (oleanolic and maslinic acid), flavonoids (luteolin, apigenine, rutin), and chalcones (olivin, olivin-diglucoside). It has been traditionally used in hypertonia, rteriosclerosis, rheumatism, gout, diabetes mellitus, and fever. OLE is antibacterial, antifungal, and antiviral. Clearing up systemic yeast is another good start (Abdel-Sattar et al., 2012).

Finally among the phytochemicals that have interest is oleuropein a substance found in the olive leaf, olive oil and olive fruit, a bitter principle of the leaves which was identified as oleuropeoside later designated oleuropein a polyphenolic secoiridoid glucoside. Biophenols are efficient components for the low incidence of cardiovascular diseases. It is potentially a rich source of a diverse range of biophenols with a wide array of biological activities (Obeid et al., 2005). The beneficial health effects of OLE have been mainly attributed to its elevated phenols content (Casalino et al., 2002). Among them, hydroxytyrosol (3,4-dihydroxyphenylethanol) stands out as a compound of high added-value, due to its interesting antioxidant and potential beneficial human health properties (Dudley et al., 2008; Hamden et al., 2009). Preventing human erythrocytes from oxidative damage induced by hydrogen peroxide (Zhang et al., 2008), anti-inflammatory antithrombotic and hypocholesterolemic effects in rats (Covas et al., 2006).

\section{A. Animal Experiments}

\section{MATERIALS AND METHODS}

Rats of original Wistar strain bred in the central animal house, Department of Biology, College of Education, Salahadden University were used in this study. Experiments were carried out in male rats weighing between 200 and $225 \mathrm{~g}$. Rats provided with a standard diet and water ad libitum. All were kept in cages with wide square mesh at the bottom and maintained in a well-ventilated animal house with $12 \mathrm{~h}$ light and dark cycle. Rats were divided into four equal groups of $10 \mathrm{rats}$ each. The first was group used as a control group and this received $1.0 \mathrm{ml}$ of physiological saline orally daily. The second group was injected Intra peritoneal (i.p) by alloxan at a single dosage of $150 \mathrm{mg} / \mathrm{kg}$ body weight. The third group was gastro-gavaged with $0.5 \mathrm{~g} / \mathrm{kg}$ body weight of OLE orally on daily basis. The fourth group was injected i.p by alloxan at a single dosage of $150 \mathrm{mg} / \mathrm{kg}$ body weight and 
gastro-gavaged with $0.5 \mathrm{~g} / \mathrm{kg}$ of OLE orally on daily basis after 5 days of alloxan injection (after induction of experimental diabetes). The experimental period was extended to thirty days. Fasting blood glucose (FBG) levels were determined weeklyduring the treatment period (Aruna et al., 1999).

\section{B. Induction of experimental diabetes}

Animals were rendered diabetic by treatment with alloxan intravenously in a daily dose of 150 $\mathrm{mg} / \mathrm{kg}$ dissolved in normal saline and injected intravenously by $1.0 \mathrm{ml}$ disposable syringe, alternatively a $20 \%$ solution of glucose injected intraperitoneal after 4-6 hr. repeat this process 5 days. After 7 days when the condition of diabetes was stabilized rats with blood glucose range of 200-300 mg/dl were selected for the study (Tamara et al. 2010).

\section{Histopathological study}

A portion of pancreatic tissue was dissected out and fixed in $10 \%$ buffered neutral formal saline and processed. After fixation tissues were cut at $5 \mu \mathrm{m}$ and stained withhematoxylin and eosin. The sections were examined under opticalmicroscope (Olympus microscope, LetizWatzler, Germany) andphotomicrographs were taken by digital camera (Sony DSC-W30, Korea). The total magnification of the microscope is calculated from the magnifying power of the objective multiplied by the magnification of the eyepiece and, where applicable, multiplied by original magnifications (Sanarya et al., 2011).

\section{Olea europaea Leaves}

Leaves of Olea europaea were collected from olive farms in Erbil city. The leaves were cleaned and washed with distilled water and dried at room temperature of $25 \mathrm{C}^{0}$ in the laboratory, the dried leaves were powdered in an electrical grinder and the powder was kept in plastic bags until used (Sanarya et al.,2011).

\section{E. Preparation of the Aqueous Extract}

The aqueous extract of olive (AEO) was prepared by soaked $50 \mathrm{gm}$ of the powdered material in one litter of distal water and kept overnight in shaking incubator at room temperature. The extract was filtrated after 24 hours and the filtrate was evaporate at a $40 \mathrm{C}^{\circ}$ under reduced pressure in a rotary evaporator and the aqueous preparation of the residue was kept in the refrigerator until used in the experiment. The OLE was suspended in distilled water andadministered orally $(0.5 \mathrm{~g} / \mathrm{kg})$ body weight (Yuanfeng et al.,1996).

\section{F. Statistical Analysis}

A statistical analysis was carried out by ANOVA after multiple comparisons Duncan's test. The data were expressed as mean \pm S.E, $\mathrm{P}<0.05$ considered a statistical difference.

\section{RESULTS}

In the present study, the table (1) shows mean values of changes in body weight in the treatment and control groups. Administration of olive leaves extract had increased the body weight.

Table 1: Mean values of body weight of the rats groups (G)

\begin{tabular}{|c|c|c|}
\hline groups & Initial body weight (g) & Final Body weight (g) \\
\hline Normal control & $224.7 \pm 0.8570^{\mathrm{d}}$ & $276.8 \pm 0.4163^{\mathrm{a}}$ \\
\hline Diabetic control & $205.6 \pm 0.0875^{\mathrm{b}}$ & $202.2 \pm 0.2802^{\mathrm{c}}$ \\
\hline Normal+ Olive leaves & $206.9 \pm 0.1828^{\mathrm{c}}$ & $255.2 \pm 0.4158^{\mathrm{d}}$ \\
\hline Diabetic+ Olive leaves & $163.6 \pm 0.1045^{\mathrm{a}}$ & $172.4 \pm 0.4010^{\mathrm{b}}$ \\
\hline
\end{tabular}

Table 2: Blood glucose value $(\mathrm{mg} / \mathrm{dl})$ of normal and experimental animals.

\begin{tabular}{|c|c|c|c|}
\hline groups & 0 Day & 15 Day & 30 Day $^{\mathrm{c}}$ \\
\hline Normal control & $118.5 \pm 0.3601^{\mathrm{d}}$ & $121.5 \pm 0.1374^{\mathrm{b}}$ & $109.7 \pm 0.0395^{\mathrm{c}}$ \\
\hline Diabetic control & $216.4 \pm 0.3173^{\mathrm{c}}$ & $413.3 \pm 0.1552^{\mathrm{d}}$ & $373.4 \pm 0.0562^{\mathrm{a}}$ \\
\hline Normal+ Olive leaves & $197.9 \pm 0.1390^{\mathrm{b}}$ & $107.0 \pm 0.4582^{\mathrm{a}}$ & $103.0 \pm 0.1425^{\mathrm{d}}$ \\
\hline Diabetic+ Olive leaves & $104.1 \pm 0.0258^{\mathrm{a}}$ & $369.3 \pm 0.2148^{\mathrm{c}}$ & $350.5 \pm 0.0348^{\mathrm{b}}$ \\
\hline
\end{tabular}

The same letters mean no significant differences.

The different letters mean significant differences at $\mathrm{p}<0.05$. 
Values are given as mean \pm S.D. for ten rats in each group. OLE produced a dose-maximum reduction in blood glucose at the 15th day of experiment in comparison with normal control $\left(109.7 \pm 0.0395^{\mathrm{c}}\right) \mathrm{mg} / \mathrm{dl}$ Table (2). Dose-dependent reduction in blood glucose was also observed in alloxan-induced diabetic rats treated with OLE. The percent reduction in blood glucose tended to be higher in the diabetic condition compared to the normal state.

A significant reduction in blood glucose of diabetic rats $\left(350.5 \pm 0.0348^{\mathrm{b}}\right) \mathrm{mg} / \mathrm{dl}$ in case of administration of OLE in comparison with diabetic control $\left(373.4 \pm 0.0562^{\mathrm{a}}\right) \mathrm{mg} / \mathrm{dl}$ Table (2).

\section{HISTOLOGICAL OBSERVATIONS}

The pancreatic islets histopathology in alloxan-OLE group showed variation in size and shape of cells associated in filtrations mononuclear inflammatorycells pancreatitis associated necrosis of epithelium lining acini with sever congestion of blood vessels (Fig. 3,4) in comparison to theanimals of the control group showed normal structures during the stages of experiment (Fig. 1). Also the alloxan -OLE group on 15 day showed mild to moderate expansion of pancreatic islets and absence of dilations with prominent hyperplastic islet (Fig. 5,6). On the day 30, the alloxan-OLE islets irregularity in size, but they appeared normal with decreased granulation group and showed that some islets appeared as very small, few cells (Fig. 7,8).

At the end of the experiment, the normal groups and some of alloxan groups showed the regular of the pancreatic islets shape associated expansion and dilated respectively (Fig.1, 9).

\section{DISCUSSION}

The present study illustrates the blood glucose lowering properties of the leaves of Olea europaea that focused onto the hypoglycemic property of this traditional plant. alloxan causes massive reduction in insulin release, through the destruction of the $\beta$-cells of the islets of Langerhans, it is interesting to note that the aqueous extract of Olea europaea at the dose $(0.5 \mathrm{~g} / \mathrm{kg})$ effectively prevented the increase in blood glucose levels. Since Alloxan induces diabetes by destroying $\beta$-cells, in the present study on OLE showed a marked antihyperglycemic effect. It is important to notice the significant increase in blood glucose levels of the alloxan diabetic rats and blood glucose levels of the alloxan treated daily with aqueous extract animals showed a significant decrease compared to the alloxan diabetic rats. This decrement was seen significantly on the second and fourth week. The results of this study reveal that a continuous administration of OLE for 30 days prevents elevation of the glucose level in blood. These results are in agreement with those of (Cardinal et al., 2001) since they showed that there was a significant decline in blood glucose levels on day 21 of the STZ diabetic rats daily treated with blue berry in Italy. The present study is in agreement with the hypoglycemic effect of the Ziryphusspina-Christi, a plant used in Egyptian folk medicine, this plant reduced blood glucose levels in STZ diabetic rats (Nesseem et al., 2009). The persistent hyperglycemia can be explained by the absence of insulin production in the destroyed $\beta$ cells. The significant increase in alloxan diabetic animals compared to control animals agrees with the results that are similar to those obtained by (Kumar et al., 2009) who used the aqueous extract of Artemisia herbal alba which is widely used in folk medicine at a dose of $0.39 \mathrm{~g} / \mathrm{kg}$ body weight for 2-4 weeks where found a significant reduction in blood glucose levels of the diabetic animals. This study reported a further reduction in blood glucose level at $p<0.05$ during the treatment with plant extract for four weeks. The present work had indicated that the aqueous crude extract of OLE at the dose used, significantly reduced blood glucose level in Alloxan diabetic rats. It is still unclear by which mechanism does OLE produce its effect on blood glucose. It is possible that the plant may reverse the catabolic features of insulin deficiency, decrease the release of glucagon or increase that of insulin, stimulate directly glycolysis in peripheral tissues increase glucose removal form blood or reduce glucose absorption from the gastrointestinal tract.

During the first week, the alloxan diabetic group showed $\beta$-cell degranulation, which might occurred as a rapid event following alloxan administration which agrees with the study of 
(Guillausseau et al., 2008). $\beta$-cell degranulation is caused mostly by the deposition of glycogen, the presence of glycogen seems to be related to the height and duration of hyperglycemia (Zunino, 2009) while islets of the alloxan - OLE group showed regular shape islets with less degranulation which means that not all islets or all $\beta$-cells are affected at the same rate since small area of the islet showed almost normal picture. Eventually, islets of hyperglycemic rats were significantly altered with their overall size gradually increasing with the duration and severity of the hyperglycemia. By the end of the second week, islets of the alloxan diabetic animals showed absence of dilations with prominent hyperplastic islet and this continued to the last week, those islets appeared regular in shape in comparison with the control group.

In a study of Juvenile diabetes (Okoli et al., 2010) elucidated that islets appear hypertrophied, therefore they showed regularity in shape with hypertrophied cells and no regular shape nuclei, or appear with atrophy, which shows irregularity in shape with atrophied cells and dense nuclei, followed by small thickening of the connectivetissue between cells. Those islets were more active than hypertrophied islets, also in the alloxan -OLE group islets showed normal shape similar to control islets. In the last week, alloxan diabetic islets showed insulitis associated mostly with lymphocyte infiltration which has been noticed in chronic juvenile diabetes similar to those of (Selvan et al., 2008). The increase in lymphocyte cells has been produced by a simple immune response which causes necrosis of islets or anti insulin serum injection, and small doses of the drug alloxan. The present study has illustrated the effect of OLE on the pancreatic islets and correlated changes observed to the levels of blood glucose. It is possible that OLE may have a direct or an indirect effect on insulin release it may be able to help diminish the complications of diabetes and support the traditional usage to control of diabetes.

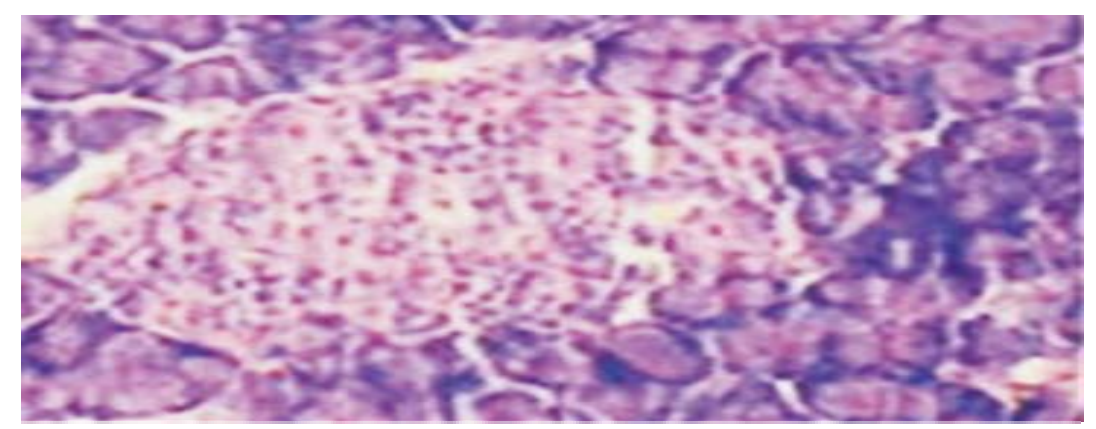

Fig. 1: Normal control rat showed presence of normal pancreatic islet cells (H\&E 400X).

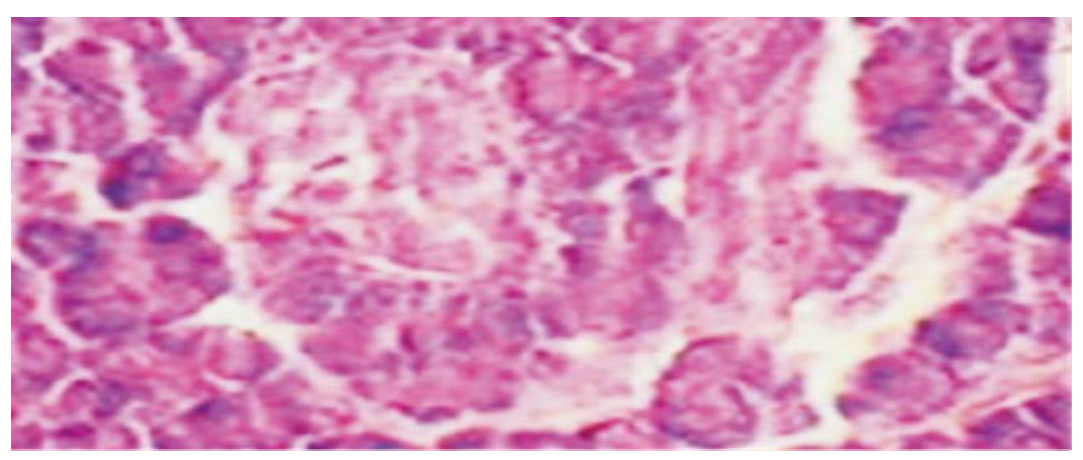

Fig. 2 : Diabetic control rats showed expansion and dilated islet cells (H\&E 400X). 


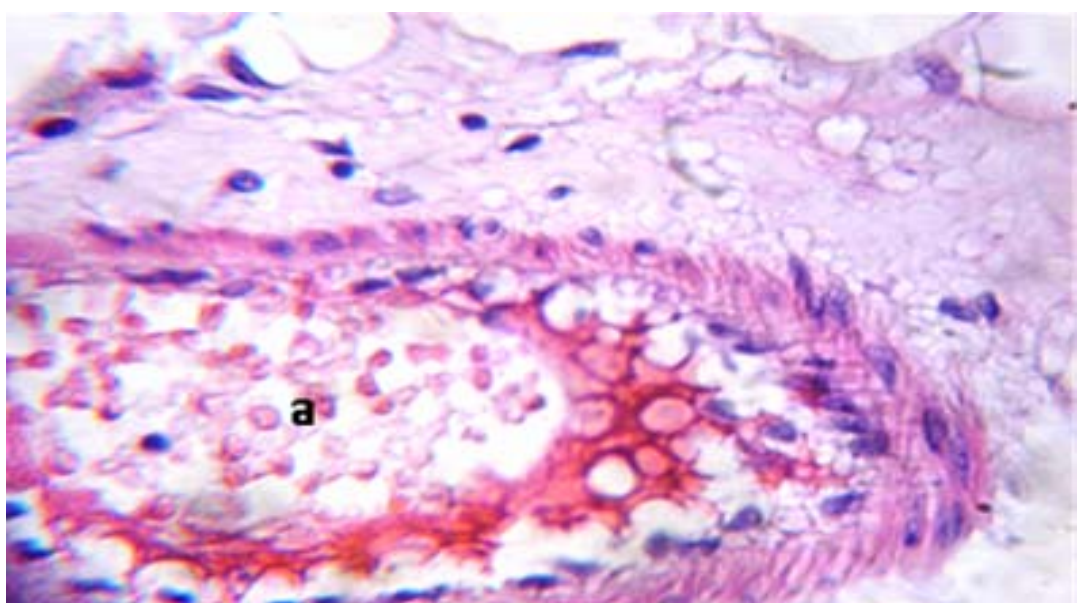

Fig. 3 : Diabetic + OLE $(0.5 \mathrm{mg} / \mathrm{kg})$ after two weeks of treated rat, showed congestive of pancreatic artery (a), (H\&E 165X).

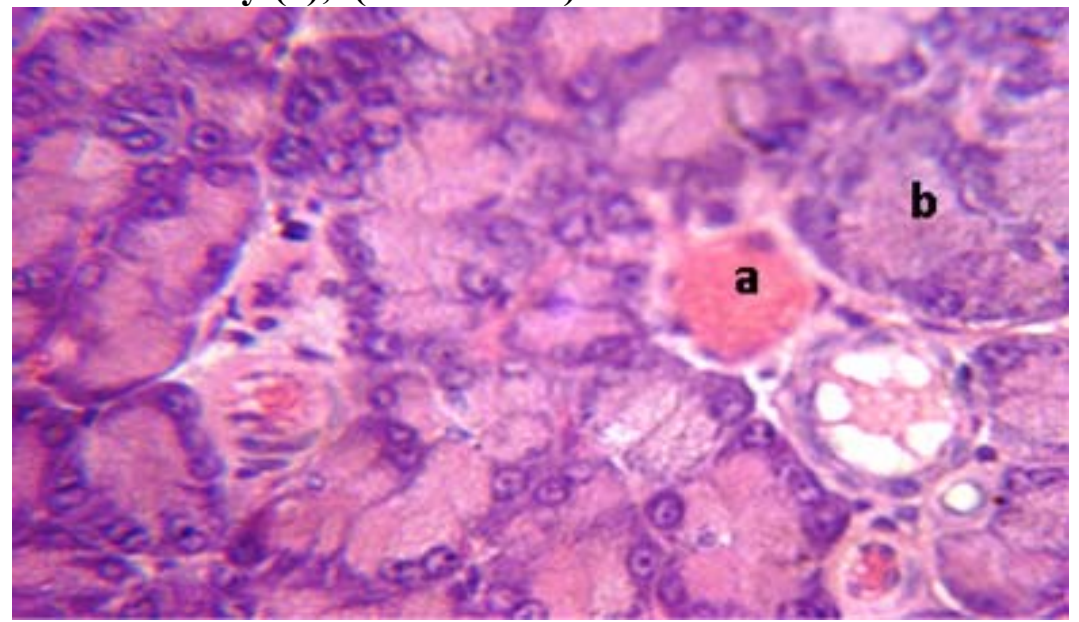

Fig. 4: Diabetic+OLE $(0.5 \mathrm{mg} / \mathrm{kg})$ after two weeksof treated rat, showed congestive of pancreatic artery (a), associated with accumulation of zymogene granule in acini (b), (H\&E 165X).

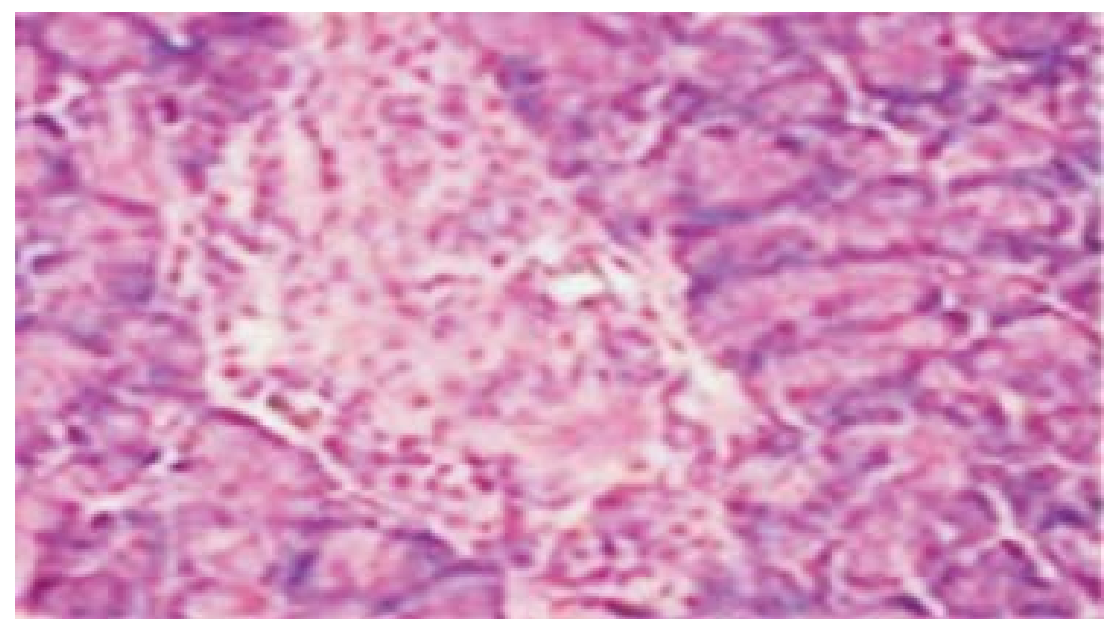

Fig. 5: Diabetic + OLE $(0.5 \mathrm{mg} / \mathrm{kg})$ after two weeks of treatment showed mild expansion and absence of dilations (H\&E 400X). 


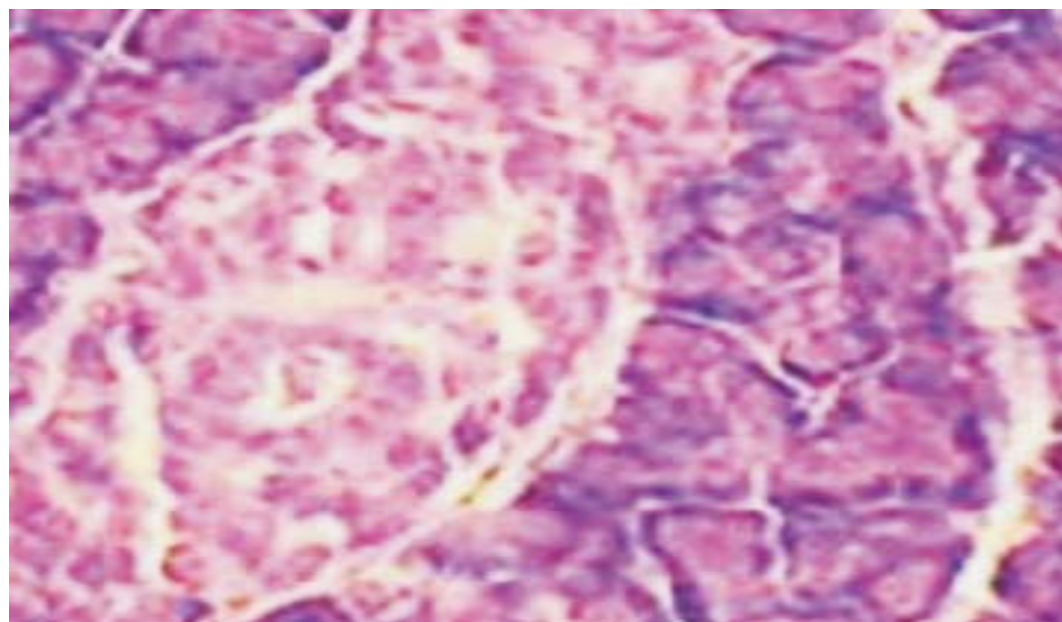

Fig. 6: Diabetic + OLE $(0.5 \mathrm{mg} / \mathrm{kg})$ after two weeks of treatment showed a moderate expansion of pancreatic islets, with a prominent hyperplastic islet $(\mathrm{H} \& \mathrm{E}$ 400X).

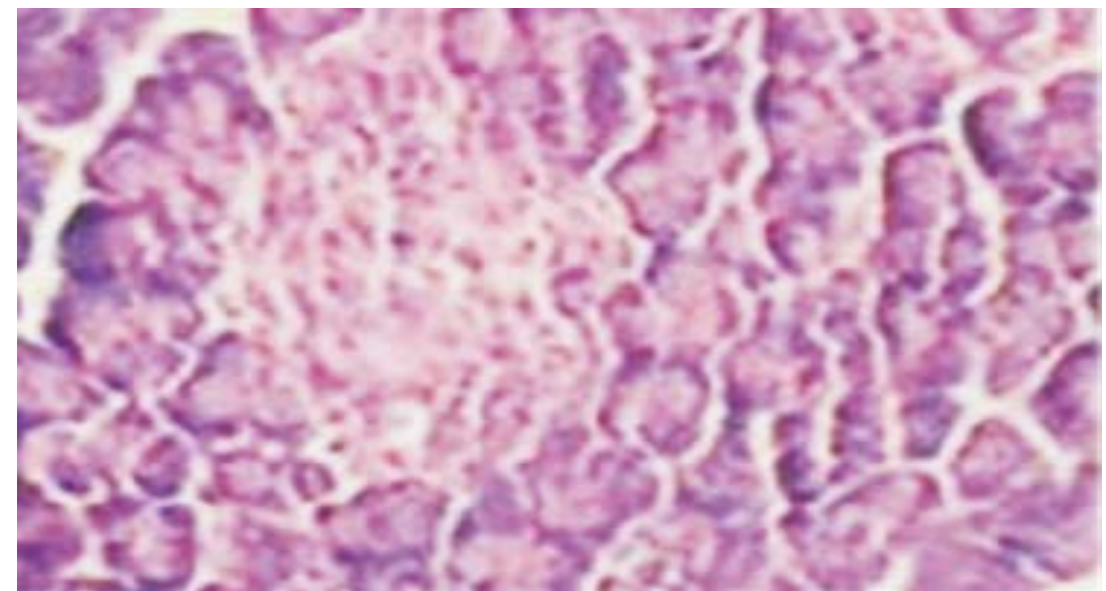

Fig. 7: Diabetic + OLE $(0.5 \mathrm{mg} / \mathrm{kg})$ after four weeks of treatment showed an absence of dilation and prominent hyperplastic of islets (H\&E 400X).

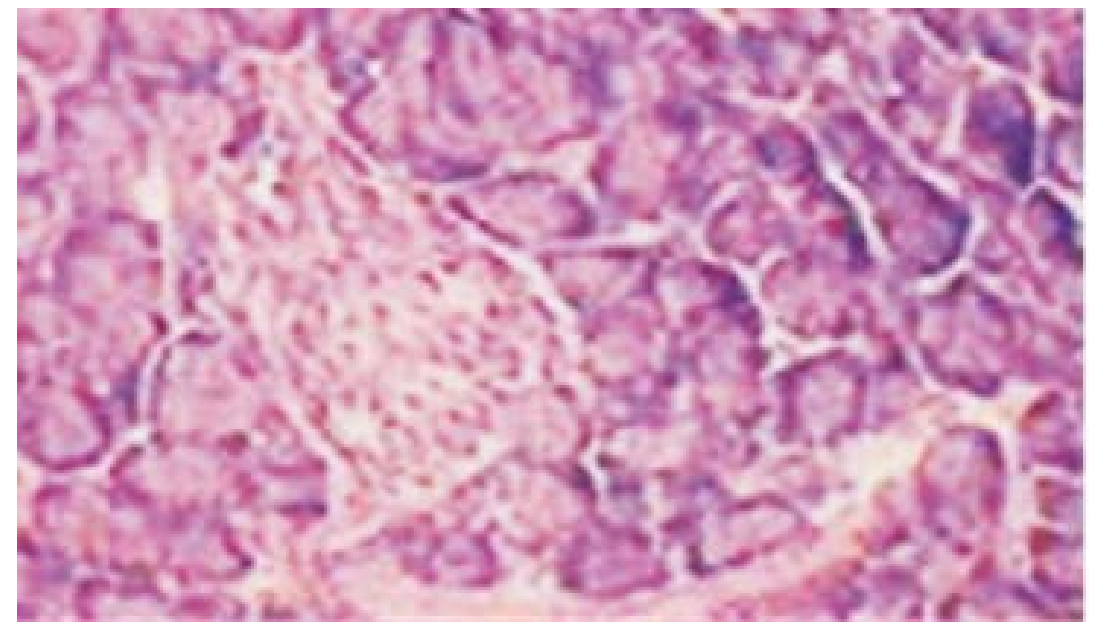

Fig. 8: Diabetic + OLE (0.5 mg/kg) after four weeks of treatment showed an absence of dilation and prominent hyperplastic of islets (H\&E 400X). 


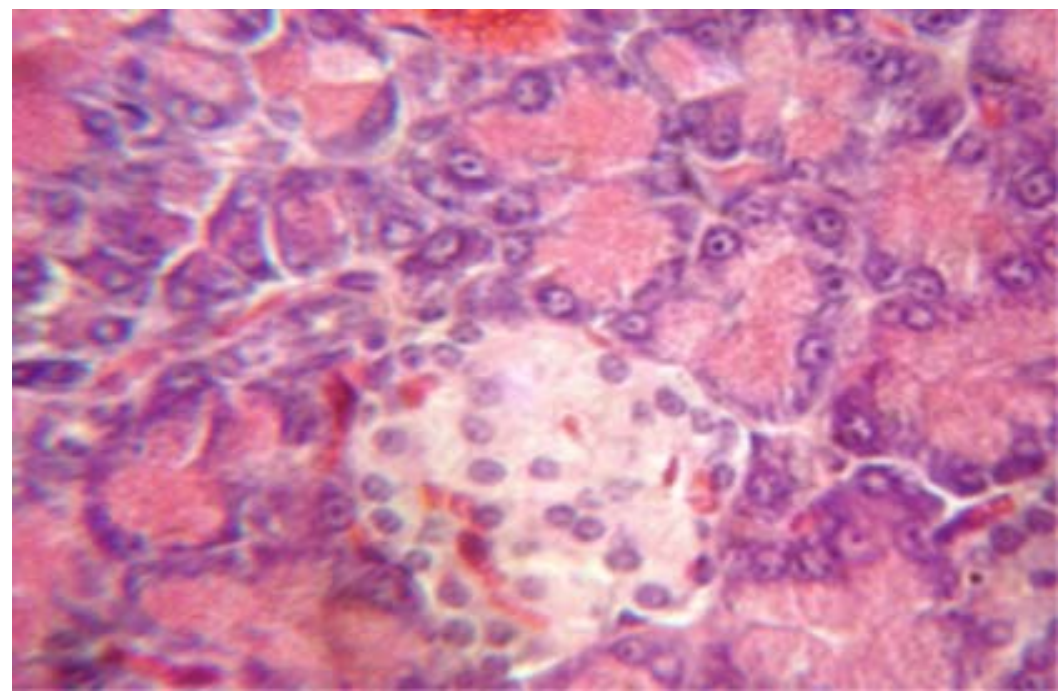

Fig. 9: Diabetic + OLE (0.5 mg/kg) after four weeks of treatment showed irregularity in size, with a decreased granulation (H\&E 165X).

\section{REFERENCES}

Abdel-Sattar, E.A.; Hossam, M.A.; Alaa, Kh.; Ashraf, B.A. (2012). Chemical and biological assessment of African olive leaf extract. Res. J. Pharma. Bio. Chem. Sci. 3(4),155-172.

Abu-zaiton, A.; Mariam A.A. (2012). Water decoction of olive leaf reduces blood glucose in normal and alloxan diabetic rats. Biol. Dep., Al- Bayt Unive, Jordan. Bangkok. ICMBPS. Sci. 100-102.

Akah, P.A.; Okoli, C.O.; Nwafor, S.V. (2002). Phytotherapy in the management of diabetes mellitus. J. Nat. Rem. 2, 1-10.

Aruna, R.V.; Ramesh, B.; Kartha, V.N. (1999). Effect of beta carotene on protein glycosylation in alloxan induced diabetic rats. Indian J. Exp. Biol. 32, 399-401.

Cardinal, J.W.; Geoffrey, P.; Margison, K.J.; Mynett, A.P.; Donald, P.C.; Rhoderick, H.E. (2001). Increased susceptibility to streptozotocin-induced $\beta$-ell apoptosis and delayed Autoimmune diabetes in Alkylpurine- DNA-N-Glycosylase-Deficient mice. Mol. Cell. Biol. 21, 5605-5613.

Casalino, E.; Calzaretti, G.C.; Sblano, V.; Landriscina, M.F.; Tecce, C. (2002). Antioxidant effect of hydroxytyrosol (DPE) and Mn2+ in liver of cadmiumintoxicated rats. Comp. Biochem. Phys. 133, 625-632.

Colca, J.R. (2006). Insulin sensitizers may prevent metabolic inflammation. Biochem. Pharmacol. 72, 125-131.

Covas, M.I.; Dela, T.K.; Farre-Albaladejo, M. (2006). Postprandial LDL phenolic content and LDL oxidation are modulated by olive oil phenolic compounds in humans. Free Radical Biol. Med. 40, 608-616.

Dudley, J.I.; Lekli, I.; Mukherjee, S.; Bertelli, A.A.; Das, D.K. (2008). Does white wine qualify for French paradox? Comparison of the cardioprotective effects of red and white wines and their constituents: resveratrol, tyrosol, and hydroxytyrosol. J. Agric. Food Chem. 56, 9362-9373.

Guillausseau, P.J.; Mean, T.; Virally, M.; Laloi-Michelin, M.; Medcau, V.; Kevorkian, J.P. (2008). Abnormalities in insulin secretion in type 2 diabetes mellitus. Diabetes Metab. 34, 43-48.

Hamden, K.; Allouche, N.; Abdelfattah- Elfeki, M.K. (2009). Hypoglycemic and antioxidant effects of phenolic extracts and purifiedhydroxytyrosol from olive mill waste in vitro and in rats. Chemico-Biological Interactions. 180, 421-432.

Karakaya, S.(2009). Olive tree(Oleaeuropaea) leaves: potential beneficial effects on human health. Nutri. Rese. 67(11), 632-8. 
Kumar, V.; Khanna, A.K.; Khan, M.M. ; Singh, R.; Singh, S.; Chander, R.; Mahdi, F.; Saxena, J.K.; Saxena, S.; Singh, V.S.; Singh, R.S. (2009). Hypoglycemic, lipid lowering and antioxidant activities in root extract of anthocephalus indices in alloxan induced diabetic rats. Indian $J$. Clini. Biochem, 24, 65-69.

Nadar, A.; Ramnanan, P.; Shode, F.O.; Somova, L.I. (2003). Antihypertensive, antiatherosclerotic and antioxidant activity of triterpenoids isolated from Olea europaea, subspecies Africana leaves. J. Ethnopharmacol. 84(2-3), 299-305.

Nesseem, D.I.; Michel, C.G.; Sleem, A.A.; El-Alfy, T.S. (2009). Formulation and evaluation of antihyperglycemic leaf extracts of Zizyphusspina-christi (L.) Willd. Pharmazie. 64,104-109.

Noor, A.; Gunasekaran, S.; Soosaihanickam, A.; Vijayalakshmi, M.A. (2008). Antidiabetic activityofaloevera and histology of organs in streptozotocin induced diabetic rats. Current Sci. 94,1070-1076.

Obeid, H.K.; Allen, M.S.; Bedgood, D.R.; Prenzied, P.; Drobards, K.; Stockmann, R. (2005). Bioactivity and analysis of biophenols recovered from olive mill waste. J. Agric. Food Chem. 53, 823-837.

Okoli, C.O.; Ibiam, A.F.; Ezike, A.C.; Akah, P.A.; Okoye, T.C. (2010). Evaluation of antidiabetic potentials of Phyllanthusniruriin alloxan diabetic rats. Dep. of Pharma. and Toxic., Faculty of Pharmaceutical Sci. Unive. of Nigeria, Nsukka, African. J. Biotechnology. 9(2), 248-259.

Sanarya, T.A.; Imad, M.A.; Karim, A.A. (2011). The effect of aqueous olive leaves extract on the pancreatic islets of streptozotocin induced diabetes mellitus in mice. Annals of microscopy. 11, 4-11.

Selvan, V.T.; Manikandan, L.; Kumar, S.G.; Suresh, R.; Kakoti, B.B.; Gomathi, P. (2008). Antidiabetic and antioxidant effects of methanol extract of Artanemasesamoidesin streptozotocin induced diabetic animals. Int. J. Appl. Res. Nat. Prod., 1, 25-33.

Tamara, C.; Djordje, M.; Ivana, S.; Dragana, D.; Stanislava, S.G. (2010). Dried leaf extract of Olea europaea ameliorates islet-directed autoimmunity in mice. Br. J. Nutri. 103, 1413-1424.

Venkatesh, S.; Reddy, G.D.; Reddy, B.M.; Ramesh, M.; Appa, A.V. (2003). Antihyperglycemic activity of Carallumaattenuata. Fitoterapia. 74, 274-279.

Verspohl, E.J. (2002). Recommended testing in diabetes research. PlantaMedica. 68, 581-590.

Yuanfeng, H.; Yufei, W.; Lijuan, W.; Hong, Z.; Hongde, Z.; Baohua, Z.; Aifang, Z. Y. (1996). Effect of nicotinmide on prevention and treatment of STZ-induced diabetes mellitus in rats. Chinese Med. J. 109, 819-822.

Zhang, X.; Jiang, L.; Geng, C.; Yoshimura, H.; Zhong, L. (2008). Inhibition of acrylamide genotoxicity in human liver-derived HepG2 cells by the antioxidant hydroxytyrosol. Chem. Biol. Interact. 176, 173-178.

Zunino, S.J. (2009). Type 2 diabetes and glycemic response to grapes or grape products. Agricultural research service. WHN. Res. C. Unive California, Davis, A.S. Nutri. 10, 17941800. 